\title{
Late Start of Surfactant Therapy and Surfactant Drug Composition as Major Causes of Failure of Phase III Multi-Center Clinical Trials of Surfactant Therapy in Adults with ARDS
}

\author{
Oleg A. Rosenberg, MD, $\mathrm{PhD}, \mathrm{ScD}^{1 *}$; Andrey E. Bautin, $\mathrm{MD}, \mathrm{PhD}, \mathrm{ScD}^{2}$; \\ Andrey A. Seiliev, $\mathrm{PhD}^{1}$ \\ 'A.M.Granov's Russian Research Center of Radiology and Surgery Technologies, St. Petersburg, Russia \\ ${ }^{2}$ Almazov National Medical Research Centre, St. Petersburg, Russia
}

\section{To the Editor:}

We have read, with great interest, the Letter to the Editor by Grotberg et al., ${ }^{(1)}$ which puts forward reduced alveolar delivery as the major cause of the unexpectedly disappointing results of phase III, multi-center, controlled clinical trials of surfactant therapy in adults with acute respiratory distress syndrome (ARDS). We do hope that this will fuel a longanticipated discussion on the causes of the failure of surfactant therapy for ARDS, despite abundant evidence from animal models with ARDS and some clinical trials that surfactant therapy is efficacious. While we strongly support Grotberg and colleagues' suggestion to further explore Grotberg's hypothesis that higher volumetric doses are needed for better drug delivery, ${ }^{(1)}$ we would like to stress that future research cannot be limited to this one direction; for apart from studies yielding positive results of therapy with natural surfactants at a volumetric dose ranging from $2.3 \mathrm{ml} / \mathrm{kg}$ to $5.4 \mathrm{ml} / \mathrm{kg}^{(2-5)}$ there are multi-center clinical trials that showed no mortality decrease in patients with ARDS despite a volumetric dose as large as $4.0 \mathrm{ml} / \mathrm{kg}$ for the drug Surfactant HL-10 ${ }^{(6)}$ and 6-8 $\mathrm{ml} / \mathrm{kg}$ for the synthetic drug Surfaxin..$^{(7)}$ Moreover, SurfactantBL from bovine lungs is administered at a dose of $6 \mathrm{mg} / \mathrm{kg}$ and a volumetric dose of $0.5-1.0 \mathrm{ml} / \mathrm{kg}$ every 12 hours, with a mortality rate fluctuating from $14.9 \%$ to $20 \%$. $^{(4,8)}$

There is no doubt that the efficacy of surfactant therapy is influenced by drug composition ${ }^{(4,8,9)}$ and the time when surfactant therapy is started. ${ }^{(4.8 .10)}$ Taeusch believes that complex natural multicomponent surfactants, which are most similar to the composition and properties of lung surfactants in situ, are more effective than simple surfactants. ${ }^{(9)}$ Synthetic

*Corresponding author: Prof. Oleg Rosenberg, $M D, P h D$ ScD. Department of Medical Biotechnology of A.M.Granov's Russian Research Center of Radiology and Surgery Technologies, St. Petersburg, Russia. E-mail: rozenberg@biosurf.ru surfactant drugs, including Surfaxine, Venticute and Exosurf, are ineffective for ARDS. ${ }^{(7,11,12)}$ Design by means of modern biotechnologies of a surfactant drug with properties similar to those of the lung surfactant in situ is deemed unfeasible. ${ }^{(14)}$ This is in line with the fact that while surfactants used in most controlled multi-center clinical trials require a dose of 200$600 \mathrm{mg} / \mathrm{kg},{ }^{(6,7,11)}$ a highly native Surfactant- BL requires a dose of only $6 \mathrm{mg} / \mathrm{kg}$ when administered twice a day. ${ }^{(4,8,10)}$ The time when surfactant therapy is started is also a major factor in surfactant efficacy. In controlled multi-center clinical trials of both native and synthetic surfactants, the first dose is administered too late, within 48-72 hours after ARDS diagnosis. ${ }^{(6,7,11,13)}$ Early administration within 24 hours after $\mathrm{PaO}_{2} / \mathrm{FiO}_{2}$ decreases to less than $200 \mathrm{mmHg}$ has been shown to be effective in clinical trials of Surfactant-BL, while a later administration of this drug has proved ineffective. ${ }^{(4,10)}$ Based on these data we believe that the major cause of the failure of phase III, multi-center, clinical trials of native surfactant drugs is late surfactant administration performed within 48-72 hours after patient intubation. ${ }^{(2,6)}$

\section{Competing interests}

The authors declare that they have no competing interests.

\section{References}

1. Grotberg JB, Filoche M, Willson DF, Raghavendran K, Notter RH. Did Reduced Alveolar Delivery of Surfactant Contribute to Negative Results in Adults with Acute Respiratory Distress Syndrome? Am J Respir Crit Care Med. 2017;195(4):538-540. doi: 10.1164/rccm.201607-1401LE. 2. Gregory TJ, Steinberg KP, Spragg R, Gadek JE, Hyers $\mathrm{TM}$, Longmore WJ, et al. Bovine surfactant therapy for patients with acute respiratory distress syndrome. Am J Respir Crit Care Med. 1997;155(4):1309-15. 
3. Walmrath D, Grimminger F, Pappert D, Knothe C, Obertacke U, Benzing A, et al. Bronchoscopic administration of bovine natural surfactant in ARDS and septic shock: impact on gas exchange and haemodynamics. Eur Respir J. 2002; 19(5):805-10.

4. Bautin AE, Osovskikh VV, Khubulava GG, Granov DA, Kozlov IA, Erokhin VV, et al. [Multicenter clinical trials of surfactantBL for the treatment of adult respiratory distress syndrome]. Klinicheskie Issledovaniya Lekarstvennykh Sredstv v Rossii. 2002;(2):18-23. [Article in Russian].

5. Willson DF, Thomas NJ, Markovitz BP, Bauman LA, DiCarlo JV, Pon S, Jacobs BR, et al.; Pediatric Acute Lung Injury and Sepsis Investigators. Effect of exogenous surfactant (calfactant) in pediatric acute lung injury: a randomized controlled trial. JAMA. 2005;293(4):470-76.

6. Kesecioglu J, Beale R, Stewart TE, Findlay GP, Rouby JJ, Holzapfel L, et al. Exogenous natural surfactant for treatment of acute lung injury and the acute respiratory distress syndrome. Am J Respir Crit Care Med. 2009;180(10):989-94. doi: 10.1164/rccm.200812-1955OC.

7. Wiswell TE, Smith RM, Katz LB, Mastroianni L, Wong DY, Willms D, et al. Bronchopulmonary segmental lavage with Surfaxin (KL(4)-surfactant) for acute respiratory distress syndrome. Am J Respir Crit Care Med. 1999;160(4):1188-95. 8. Bautin A, Khubulava G, Kozlov I, Poptzov V, Osovskikh
V, Seiliev A, Volchkov V, Rosenberg O. Surfactant therapy for patients with ARDS after cardiac surgery. J Liposome Research. 2006;16(3):265-72.

9. Taeusch HW, Karen LU, Ramierez-Schrempp D. Improving pulmonary surfactants. Acta Pharmacol Sin. 2002; 23 Supplement:11-15.

10. Rosenberg OA, Bautin AE, Osovskich VV, Tsibulkin EK, Gavrilin SV, Kozlov I.A. When to start surfactant therapy (STtherapy) of acute lung injury? Abstracts of the 11th ERS Annual Congress. Berlin, Germany, September 22-26, 2001. Eur Respir J. 2001;18 (Suppl 38): P153, 7s.

11. Spragg RG, Lewis JF, Walmrath HD, Johannigman J, Bellingan G, Laterre PF, et al. Effect of recombinant surfactant protein $\mathrm{C}$-based surfactant on the acute respiratory distress syndrome. N Engl J Med 2004;351(9):884-92.

12. Willson DF, Truwit JD, Conaway MR, Traul CS, Egan EE. The Adult Calfactant in Acute Respiratory Distress Syndrome Trial. Chest. 2015;148(2):356-364. doi: 10.1378/chest.14-1139. 13. Anzueto A, Jubran A, Ohar JA, Piquette CA, Rennard SI, Colice G, et al. Effects of aerosolized surfactant in patients with stable chronic bronchitis: a prospective randomized controlled trial. JAMA. 1997;278(17):1426-31.

14. Willson D, Notter R. The future of exogenous surfactant therapy. Respir Care. 2011;56(9):1369-86; discussion 1386-8. doi: $10.4187 /$ respcare. 01306 . 